\title{
PEMANFAATAN MINYAK ATSIRI KULIT BUAH HONJE SEBAGAI ANTIOKSIDAN PRODUK SOSIS AYAM
}

\author{
[Utilization of Essential Oil from Honje Fruit Skin as Antioxidant for Chicken Sausages]
}

\author{
Dede Sukandar*, Anna Muawanah, Tarso Rudiana, dan Khilda Fithri Aryani
}

Program Studi Kimia, Fakultas Sains dan Teknologi UIN Syarif Hidayatullah, Jakarta

Diterima 27 September 2016 / Disetujui 23 Maret 2017

\begin{abstract}
A study on the inhibition of oxidative deterioriation of chicken sausage products added with essential oil from honje (Etlingera elatior) fruit skin was conducted. The pumose of this study was to detemine the antioxidative activity of essential oils of fruit peels of honje and its effect on the inhibition of oxidative deterioration of chicken sausage products. The antioxidant activity assay of the essential oils and chicken sausages added with 0,50,100, and $160 \mu \mathrm{g} / \mathrm{mL}$ essential oil was then analyzed. The best formula of chicken sausages was determined by organoleptic test, i.e.a hedonic test on untrained panelists and by the inhibition of oxidative deterioration measured as malondialdehyde content. In addition, analysis of moisture, ash, fat, protein, carb ohydrate, metal contamination and microbial contamination of the sausages was also done. The results showed that the essential oil of the honje fruit skin had an antioxidant activity $\left(I C_{50}\right)$ of $21.296 \mathrm{mg} / \mathrm{mL}$, and the best chicken sausages was those added with $\mu \mathrm{g} / \mathrm{mL}$ essential oils. The characteristics of the best chicken sausages complied with SNI 01-3820-1995 sausage quality standard, with water content of $66.75 \%(w / w)$; ash content of $1.26 \%(w / w) ;$ fat content of $2.90 \%(w / w)$; protein content of $23.10 \%$ (w/w); carbohydrate content of 5.99\% (w/w); Metal Zn $14.17 \mathrm{mg} / \mathrm{kg} ; \mathrm{Cu} 0.65 \mathrm{mg} / \mathrm{kg}$; and no microbial contamination.
\end{abstract}

Keywords: antioxidants, chicken sausage, essential oils, honje rind

\begin{abstract}
ABSTRAK
Peneltian terhadap penghambatan kerusakan oksidatif produk sosis ayam yang ditambahkan minyak atsin kulit buah honje (Etlingera elatior) telah berhasil dilakukan. Tujuan dari penelitian ini adalah mengetahui aktivitas antioksidan minyak atsin kulit buah honje dan pengaruhnya terhadap penghambatan kerusakan oksidatif produk sos is ayam. Pengujian aktivitas antioksidan min yak atsiri dilakukan terhadap sosis ayam dengan konsentrasi minyak atsin 0;0,550; 100; dan $160 \mu \mathrm{g} / \mathrm{mL}$. Formula yang terbaik dipilih dari hasil uji organoleptik dengan metode uji hedonik menggunakan panelis tidak terlatih dan hasil uji penghambatan kenusakan oksidatif dengan metode uji daya hambat pembentukan malondialdehid. Selain itu, dilakukan pengujian kadar air, abu, lemak, protein, karbohidrat, cemaran logam, dan cemaran mikroba. Hasil penelitian menunjukkan bahwa minyak atsin kulit buah honje memiliki aktivitas antioksidan $\left(\mathrm{IC}_{50}\right)$ $21,296 \mathrm{mg} / \mathrm{mL}$ dan sosis ayam terbaik yang paling disukai, memiliki daya hambat oksidatif tertinggi $19,41 \%$ dan karakteristik proksimat memenuhi standar mutu sosis SNI 01-3820-1995 adalah yang ditambahkan minyak atsiri $160 \mu \mathrm{g} / \mathrm{mL}$. Karakteristik sosis terbaik memiliki kadar air 66,75\% (b/b); kadar abu 1,26\% (b/b); kadar lemak 2,90\% (b/b); kadar protein 23,10\% (b/b); kadar karbohidrat 5,99\% (b/b); logam Zn 14,17 mg/kg; logam Cu 0,65 mg/kg; dan tidak memiliki cemaran mikroba.
\end{abstract}

Kata kunci: antioksidan, kulitbuah honje, minyak atsiri, sosis ayam

\section{PENDAHULUAN}

Daging ayam merupakan jenis pangan yang mudah mengalami kerusakan akibat komposisinya berupa lemak dan air, disamping karbohidrat dan protein (Mudawaroch dan Zulfanita, 2012). Salah satu pangan olahan daging ayam yang sangat di-

*Penulis Korespondensi:

E-mail: sukandarkimia@uinjkt.ac.id gemari masyarakat Indonesia ialah sosis. Kandungan lemak pada sosis merupakan bagian yang sangat penting untuk menghasilkan tekstur dan rasa yang baik (Vural, 2003) Akan tetapi, kadar lemak dikaitkan dengan tingginya tingkat oksidasi lipid selama penyimpanan, penerimaan konsumen pun akan menurun karena terjadinya ketengikan yang disebabkan oleh oksidasi lipid dan pertumbuhan mikroba (Bradley et al., 2011). Min dan Boff (2002) juga menyebutkan selain menyebabkan flavor dan 
rasa tidak disukai, proses oksidasi pada pangan juga dapat menurunkan nilai gizi. Oleh karena itu, perlu adanya antioksidan yang dapat menghambat terjadinya reaksi oksidasi lemak pada produk sosis sehingga dapat mempertahankan kualitas dan menjaga keamanan produk untuk dikonsumsi (Mudawaroch dan Zulfanita, 2012).

Antioksidan yang sering ditambahkan dalam pembuatan sosis ialah antioksidan sentetik yang diperbolehkan dalam produk pangan seperti BHA dan BHT. Pemakaian antioksidan sintetis secara berlebihan diduga sebagai agen karsinogenik penyebab penyakit kanker (Fitriana et al., 2015). Dampak negatif dari pemakaian antioksidan sintetis yang berlebihan dapat dihindari dengan memanfaatkan antioksidan alami sebagai salah satu pilihan alternatif yang aman untuk campuran bahan pangan. Salah satu tanaman yang berpotensi sebagai sumber antioksidan alami ialah tanaman honje. Hasil penelitian oleh Jaafar et al. (2007) pada daun, batang, bunga, dan rimpang tanaman ini menunjukkan adanya minyak atsiri yang diduga bersifat antioksidan.

Penelitian penghambatan oksidasi produk daging pernah dilkukan dengan menggunakan bubur daun sirih untuk menghambat kerusakan oksidasi pada dendeng sapi selama penyimpanan. Tingkat ketengikan dendeng dinyatakan dengan angka Tiobarbituric Acid (TBA), pada dendeng yang direndam bubur daun sirih dan disimpan selama 3 bulan memiliki angka TBA yang relatifr rendah yaitu $0,0168 \mu \mathrm{mol} \mathrm{MA} / \mathrm{kg}$ (Legowo et al., 2002). Batas toleransi bahan pangan yang masih bias dikonsumsi maksimal angka TBA adalah $18 \mu \mathrm{mol} \mathrm{MA} / \mathrm{kg}$.

Menurut Jaafar et al. (2007) dan Chan et al. (2007), pada rimpang honje ditemukan senyawa alkaloid, flavonoid dan minyak atsiri yang bertindak sebagai antioksidan. Berdasarkan penelitian (Jaafar et al., 2007; Chan et al., 2007) tersebut menyimpulkan bahwa minyak atsiri tanaman honje diduga memiliki sifat antioksidan dan penelitian mengenai aktivitas antioksidan minyak atsiri pada bagian kulit buah honje belum pernah dilakukan. Oleh karena itu, penelitian ini bertujuan mengetahui aktivitas antioksidan minyak atsiri kulit buah honje dan pengaruhnya terhadap penghambatan kerusakan oksidatif produk sosis ayam.

\section{BAHAN DAN METODE}

\section{Bahan}

Bahan yang digunakan adalah kulit buah honje yang diperoleh dari Kabupaten Pangandaran, serta bahan yang digunakan dalam pembuatan sosis ayam.

\section{Destilasi minyak atsiri kulit buah honje}

Sampel kulit buah honje hasil pengeringan (dikering anginkan) didestilasi dengan cara destilasi uap. Metode destilasi uap menyerupai kukusan, dimana sampel kulit buah honje disimpan pada bagian atas saringan, setelah itu ketel ditutup rapat kemudian dipanaskan dengan suhu titik didih $\pm 150^{\circ} \mathrm{C}$ dan tekanan 1 atm selama $4-6$ jam.

\section{Uji aktivitas antioksidan minyak atsiri kulit buah honje (Cahyana et al., 2003)}

Sampel minyak atsiri kulit buah honje dilarutkan dalam etanol (Merck, Germany) pada berbagai konsentrasi (1-25 $\mathrm{mg} / \mathrm{mL}$ ). Masing-masing dari konsentrasi tersebut diambil $2 \mathrm{~mL}$ sampel dan dimasukkan kedalam tabung reaksi lalu ditambahkan $2 \mathrm{~mL}$ larutan DPPH (Sigma-Aldrich) 0,002\% dan divorteks sampai homogen. Selanjutnya diinkubasi selama 30 menit dan diukur absorbansi campuran tersebut pada panjang gelombang $517 \mathrm{~nm}$ pada spektrofotometer UV-Vis (Lambda 25 Perkin Elmer). Pengukuran dilakukan pengulangan sebanyak 3 kali. Sebagai standar digunakan BHA (Merck, Germany) dengan perlakuan yang sama dengan sampel uji.

\section{Pembuatan sosis ayam dengan minyak atsiri kulit buah honje (Kingchaiyaphum, 2012)}

Pembuatan sosis ayam dilakukan mengacu pada metode Kingchaiyaphum (2012). Minyak atsiri hasil pengenceran dengan minyak goreng dimasukkan ke dalam adonan sosis ayam dengan konsentrasi 50, 100, $160 \mu \mathrm{g} / \mathrm{mL}$, masing-masing sebanyak $1 \mathrm{~mL}$, dan tanpa penambahan minyak atsiri sebagai kontrol (Tabel 1). Setelah sosis matang, sosis disimpan pada suhu dingin $\left(10^{\circ} \mathrm{C}\right)$ sampai sosis dilakukan pengujian antioksidan.

Tabel 1. Formulasi sosis ayam dengan minyak atsiri kulit buah honje

\begin{tabular}{|c|c|c|c|c|}
\hline \multirow{2}{*}{ Bahan } & \multicolumn{4}{|c|}{ Perlakuan } \\
\hline & $\overline{\text { Kontrol }}$ & 1 & II & III \\
\hline Daging ayam (\%) & 67 & 67 & 67 & 67 \\
\hline Tepung tapioka (\%) & 22 & 22 & 22 & 22 \\
\hline Garam (\%) & 0,77 & 0,77 & 0,77 & 0,77 \\
\hline Gula (\%) & 0,77 & 0,77 & 0,77 & 0,77 \\
\hline Merica (\%) & 0,22 & 0,22 & 0,22 & 0,22 \\
\hline Bawang putih (\%) & 1,67 & 1,67 & 1,67 & 1,67 \\
\hline Es (\%) & 1,67 & 1,67 & 1,67 & 1,67 \\
\hline Putih telur (\%) & 5,55 & 5,55 & 5,55 & 5,55 \\
\hline Minyak jagung (\%) & 0,40 & 0,40 & 0,40 & 0,40 \\
\hline $\begin{array}{l}\text { Minyak atsiri } \\
\text { honje }(\mu \mathrm{g} / \mathrm{mL})\end{array}$ & 0 & 50 & 100 & 160 \\
\hline $\begin{array}{l}\text { Keterangan: I = Sosi } \\
\text { atsin kulit buah } \\
\text { dengan penamb } \\
100 \mu \mathrm{g} / \mathrm{mL} \text {; III = } \\
\text { minyak atsiri kulit }\end{array}$ & nje 16 & ena & & $\begin{array}{l}\text { ninyak } \\
\text { ayam } \\
\text { honje } \\
\text { bahan }\end{array}$ \\
\hline
\end{tabular}


Uji daya hambat dekomposisi peroksida pada sosis ayam (Kingchaiyaphum dan Chitsiri, 2012)

Uji daya hambat dekomposisi peroksida dilakukan dengan cara menganalisis pembentukan MDA, dengan tiga kali ulangan $(n=3)$. Pada uji ini, masing-masing sampel sosis dan sosis kontrol disimpan selama 5 minggu pada suhu $10^{\circ} \mathrm{C}$. Setiap sepekan dianalisis bilangan MDA-nya. Proses pengujian MDA diawali dengan menimbang sebanyak $10 \mathrm{~g}$ dan diblender dengan $50 \mathrm{~mL}$ akuades, setelah itu campuran tersebut dipindahkan ke dalam labu destilasi dan ditambahkan 47,5 mL akuades lagi dan 2,5 mL HCl (Merck, Germany) 4 N. Kemudian didestilasi selama \pm 90 menit (sampai volume destilat yang dihasilkan $\pm 50 \mathrm{~mL}$ ). Setiap destilat diambil 3 $\mathrm{mL}$ dan ditambahkan $1 \mathrm{~mL}$ pereaksi asam 2-tiobarbiturat (TBA) (Merck, Germany) 0,37\% dalam $\mathrm{HCl}$ $0,25 \mathrm{~N}$ (dilakukan pengulangan sebanyak 3 kali). Tabung reaksi dipanaskan dalam penangas air mendidih selama 30 menit sampai berubah warna menjadi merah kemudian didinginkan pada suhu ruang dandiukur absorbansinya pada panjang gelombang $530 \mathrm{~nm}$. Blanko yang digunakan adalah $3 \mathrm{~mL}$ akuades dan $1 \mathrm{~mL}$ pereaksi TBA. Aktivitas antioksidan ditentukan berdasarkan nilai kadar TBARS yang dihitung dari kurva standar malondialdehid (standar 1,1,3,3-tetraetoksi propan).

\section{Uji mutu organoleptik (Soekarto dan Hubeis, 1991)}

Pengujian organoleptik dilakukan dengan uji hedonik/kesukaan terhadap keempat perlakuan penambahan minyak atsiri kulit biji honje. Uji Organoleptik ini dilakukan oleh kelompok panelis tidak terlatih yaitu panelis yang telah mendapat pengarahan singkat agar memiliki kepekaan yang lebih baik dibandingkan panelis umum yang berjumlah 21 orang. Panelis berperan dalam menguji parameter warna, aroma, tekstur, dan rasa dengan skala hedonik berkisar antara 1 sampai 5, dimana (5) Sangat Suka (4) Suka (3) Agak Suka (2) Tidak Suka (1) Sangat Tidak Suka.

\section{Analisis proksimat}

Analisis proksimat meliputi uji kadar air, kadar abu, kadar protein, kadar lemak (AOAC, 1995), kadar karbohidrat (Kurniawan, 2013), cemaran logam mengunakan AAS merek AA Analyst 700 Perkin Elmer (AOAC, 1995; BSN, 1998), dan cemaran total bakteri yang menimbulkan kerusakan pada makanan menggunakan metode Total Plate Count, TPC (Fardiaz, 1992).

\section{HASIL DAN PEMBAHASAN}

\section{Minyak atsiri kulit buah honje}

Minyak atsiri kulit buah honje (Etlingera elatior) yang dihasilkan melalui proses distilasi uap dan air ini berupa cairan jernih kekuningan dan beraroma khas. Hasil distilasi sampel kering kulit buah honje sebanyak $30,4 \mathrm{~kg}$ memperoleh minyak atsiri sebanyak $49,4 \mathrm{~mL}$ dengan rendemen sebesar $0,163 \%$.

\section{Aktivitas antioksidan minyak atsiri kulit buah honje}

Hasil pengujian menunjukkan aktivitas antioksidan yang dimiliki minyak atsiri kulit buah honje dengan nilai $I_{50}$ sebesar 21,296 $\pm 0,789 \mathrm{mg} / \mathrm{mL}$ sedangkan aktivitas antioksidan $\left(\mathrm{IC}_{50}\right) \mathrm{BHA}$ sebesar $0,00895 \pm 0,08784 \mathrm{mg} / \mathrm{mL}$, hasil tersebut menunjukkan bahwa minyak atsiri kulit buah honje memiliki aktivitas antioksidan rendah. Hal ini disebabkan minyak atsiri kulit buah honje hanya mengandung senyawa antioksidan eugenol 3,26\% (Sukandar et al., 2014). Eugenol diketahui memiliki sifat antioksidan yang sangat baik karena eugenol mengandung gugus fenolik. Politeo et al. (2006) menyebutkan bahwa kuat atau lemahnya aktivitas antioksidan yang dimiliki minyak atsiri berbagai tanaman dipengaruhi komponen senyawa penyusun yang bersifat antioksidan salah satunya eugenol. Eugenol bersifat sebagai antioksidan dengan cara mendonorkan hidrogennya menjadi radikal fenoksi, kemudian radikal fenoksi eugenol akan beresonansi untuk mencapai kondisi stabil, reaksi disajikan pada Gambar 1. Meskipun komposisi eugenol yang dimiliki minyak atsiri kulit buah honje sedikit, namun aktivitas antioksidan minyak atsiri kulit buah honje lebih baik dibandingkan aktivitas antioksidan minyak atsiri parsley dengan $I_{50}$ sebesar $80,21 \mathrm{mg} / \mathrm{mL}$ (Zhang et al., 2006), dan minyak atsiri lada hitam sebesar $37,58 \mathrm{mg} / \mathrm{mL}$ (Politeo et al., 2006).

\section{Daya hambat dekomposisi peroksida pada sosis ayam}

Daya hambat dekomposisi peroksida dapat dianalisis berdasarkan perubahan kadar MDA. Perubahan kadar MDA pada formulasi sosis selama minggu kedua sampai minggu keempat (Gambar 2) disebabkan adanya oksidasi asam-asam lemak tidak jenuh pada sosis selama penyimpanan. Pada minggu kelima kadar MDA formulasi sosis tidak mengalami peningkatan lagi. Kadar MDA yang konstan pada minggu kelima dapat disebabkan oleh proses oksidasi yang mencapai titik maksimal atau bahkan sudah tidak ada lagi senyawa aldehid yang dapat teridentifikasi dalam sampel sosis. Oleh karena itu pengukuran kadar MDA minggu ke empat dari masa penyimpanan formulasi sosis dapat dikatakan sebagai kondisi optimum. Pada kondisi optimum ini dapat terlihat bahwa minyak atsiri pada formula sosis memberikan pengaruh penghambatan terhadap terjadinya oksidasi lemak yang ditandai dengan sedikitnya kadar MDA yang terbentuk dibandingkan sosis kontrol. 


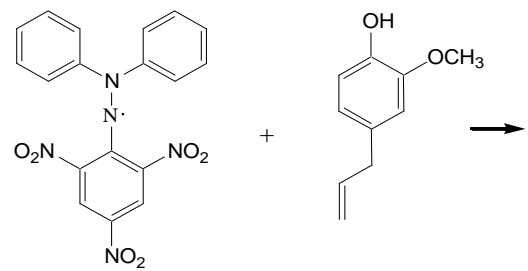

Radikal DPPH

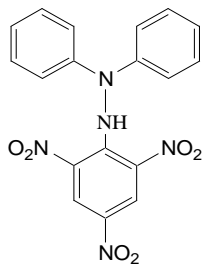

DPPH

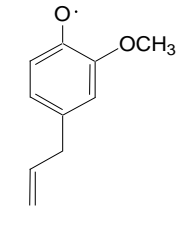

Radikal Eugenol
A

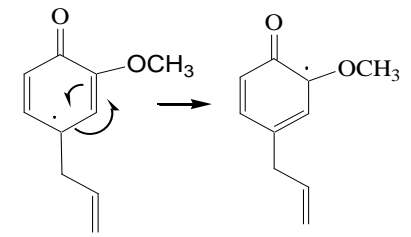

B

Gambar 1. Reaksi antioksidan eugenol (A) dan resonansi radikal eugenol (B) (Aini et al., 2007)

Daya hambat minyak atsiri kulit buah honje terhadap pembentukan MDA pada ketiga produk sosis masing-masing sebesar 8,$14 ; 14,90$; dan $19,41 \%$. Hal ini menunjukkan bahwa semakin tinggi konsentrasi minyak atsiri kulit buah honje pada sosis ayam semakin tinggi pula aktivitas penghambatan MDA yang terjadi dalam sosis. Data penghambatan terhadap pembentukan MDA ini juga telah dianalisis dengan metode statisika Duncan dengan tiga kali ulangan $(n=3)$, hasilnya adalah ke empat sosis dengan penambahan minyak atsiri dari kulit biji honje yang berbeda pada minggu ke empat, memiliki daya hambat yang berbeda nyata $(P<0,05)$. Artinya penambahan minyak atsiri dengan konsentrasi yang berbeda dapat memengaruhi proses penghambatan oksidasi lipid dalam produk sosis ayam, sehingga penambahan minyak atsiri kulit buah honje sebanyak $160 \mu \mathrm{g} / \mathrm{mL}$ dapat dikatakan memberikan efek penghambatan secara maksimal. Peroksidasi lipid tak jenuh dapat menghasilkan hidrogenperoksida. Senyawa hidrogen peroksida mudah terdekomposisi menjadi senyawa volatil berupa aldehid dan asam karboksilat yang menimbulkan aroma tengik pada makanan berlemak. Selain itu hidrogenperoksida berperan aktif dalam menyebabkan kerusakan sel serta pemicu penyakitpenyakit akibat oksidasi. Hidroperoksida (hasil oskidasi) terbentuk cepat dengan adanya radikal bebas dan logam-logam pengkatalis serta faktor cahaya atau panas. Hidrogenperoksida yang terbentuk akan mengalami dekomposisi, membentuk senyawa malondialdehida. Aktivitas antioksidan dapat diukur berdasarkan penghambatan MDA. Malondialdehid merupakan produk sekunder dari oksidasi asam lemak tak jenuh sebagai hasil dekomposisi peroksida (Bangol et al., 2014).

Proses oksidasi pada lemak terjadi secara autooksidasi dimana lemak yang mengandung asam lemak tidak jenuh akan berubah menjadi radikal bebas pada tahap inisiasi yang prosesnya terjadi secara lambat. Radikal ini bereaksi secara cepat dengan oksigen udara menghasilkan radikal peroksi, hidroperoksida dan radikal baru ketika bereaksi dengan asam lemak tidak jenuh yang lain (tahap propagasi). Tahap tersebut menyebabkan peningkatan pembentukan produk oksidasi primer dan sekunder (Porter et al., 1995). MDA merupakan produk oksidasi sekunder yang dihasilkan oleh dekomposisi hidroperoksida yang bersifat tidak stabil. Selain aldehid produk reaksi oksidasi yang lain adalah keton, karbonil dan asam-asam organik (DeMan, 1999). Senyawa senyawa tersebut yang menyebabkan perubahan aroma makanan berlemak menjadi tengik yang dikhawatirkan terjadi pada sosis yang telah disimpan.

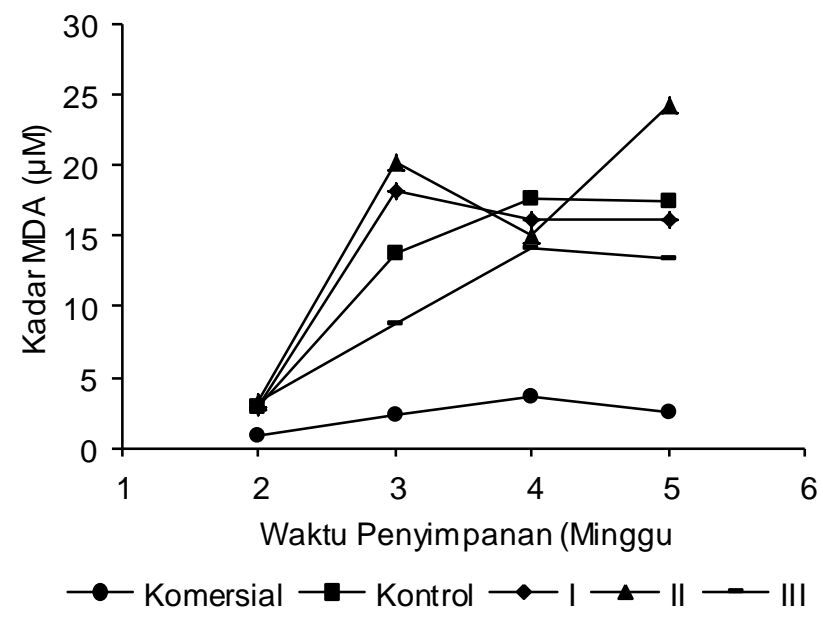

Gambar 2. Kadar pembentukan MDA pada formulasi sosis selama lima minggu dengan suhu penyimpanan $10^{\circ} \mathrm{C}$

Sosis merupakan makanan berkadar air tinggi dan penyimpanannya dalam suhu dingin bahkan suhu beku. Pada suhu rendah seperti pembekuan reaksi oksidasi lemak tetap akan terjadi sehingga sangat dibutuhkan bahan antioksidan untuk menjaga agar kualitas sosis tidak mengalami ketengikan. 
Minyak atsiri kulit biji honje ternyata mampu membantu menurunkan nilai bilangan MDA selama penyimpanan.

\section{Mutu organoleptik sosis}

Pengujian mutu organoleptik sosis ayam dengan formulasi minyak atsiri kulit buah honje ini dimaksudkan untuk mengetahui seberapa besar pengaruh minyak atsiri kulit buah honje dalam perubahan sensorik sosis ayam. Data organoleptik dianalisa dengan cara statistik ANOVA, dimana jumlah panelis, $n=21$ (Tabel 2). Hasil analisis untuk parameter uji tekstur, warna, dan rasa tidak ada perbedaan nyata, sedangkan untuk parameter aroma dan rata-rata kesukaan dari keempat formulasi menunjukkan adanya perbedaan karena nilai $\operatorname{sig} \alpha \leq 0,05$.

Hasil uji organoleptik kesukaan menunjukkan bahwa rata-rata panelis memberikan skala 3,1 sampai 3,6 untuk semua formula sosis ayam dan skala 2,8 untuk sosis kontrol. Rata-rata kesukaan panelis tertinggi terdapat pada formula sosis dengan konsentrasi minyak atsiri $160 \mu \mathrm{g} / \mathrm{mL}$. Penambahan minyak atsiri kulit buah honje pada formula sosis ayam ini memberikan pengaruh positif terhadap aroma sosis ayam. Aroma minyak atsiri yang khas mampu menutupi bau daging ayam yang tajam (amis) pada sosis.

Tabel 2. Hasil analisis statistika uji organoleptik sosis ayam

\begin{tabular}{lcccc}
\hline Parameter & \multicolumn{4}{c}{ Rata-rata Perlakuan \pm SD } \\
\cline { 2 - 5 } Uji & Kontrol & I & II & III \\
\hline Tekstur & $3,0 \pm$ & $3,3 \pm$ & $3,3 \pm$ & $3,4 \pm$ \\
& $0,9^{\mathrm{a}}$ & $0,7^{\mathrm{a}}$ & $0,8^{\mathrm{a}}$ & $0,7^{\mathrm{a}}$ \\
Warna & $3,3 \pm$ & $3,3 \pm$ & $3,5 \pm$ & $3,5 \pm$ \\
& $0,8^{\mathrm{a}}$ & $0,7^{\mathrm{a}}$ & $0,6^{\mathrm{a}}$ & $0,7^{\mathrm{a}}$ \\
Aroma & $3,1 \pm$ & $3,5 \pm$ & $3,5 \pm$ & $3,8 \pm$ \\
& $0,94^{\mathrm{a}}$ & $0,9^{\mathrm{ab}}$ & $0,6^{\mathrm{ab}}$ & $0,6^{\mathrm{b}}$ \\
Rasa & $2,9 \pm$ & $3,0 \pm$ & $3,3 \pm$ & $3,5 \pm$ \\
& $0,9^{\mathrm{a}}$ & $1,0^{\mathrm{a}}$ & $0,9^{\mathrm{a}}$ & $0,9^{\mathrm{a}}$ \\
Kesukaan & $2,8 \pm$ & $3,1 \pm$ & $3,2 \pm$ & $3,6 \pm$ \\
& $0,8^{\mathrm{a}}$ & $0,9^{\mathrm{ab}}$ & $0,8^{\mathrm{ab}}$ & $0,9^{\mathrm{b}}$ \\
\hline
\end{tabular}

Keterangan: Pangkat abjad yang berbeda pada baris yang sama menunjukkan hasil yang berbeda nyata pada $P<0,05$, jumlah panelis $(n)=21 ; I=$ Sos is ayam dengan penambahan minyak atsiri kulit buah honje $50 \mu \mathrm{g} / \mathrm{mL}$; II = Sosis ayam dengan penambahan minyak atsiri kulit buah honje $100 \mu \mathrm{g} / \mathrm{mL}$; III = Sosis ayam dengan penambahan minyak ats iri kulitbuah honje $160 \mu \mathrm{g} / \mathrm{mL}$

Berdasarkan Howard et al. (2012) jumlah panelis tidak terlatih (untrained) minimal 75 orang, panelis terlatih (trained) minimal sebanyak 10 orang dan panelis ahli (expert) minimal sebanyak 6 orang. Karena pada penelitian ini jumlah panelis tidak terlatih sebanyak 21 orang, maka hasil uji organoleptik hanya dapat memberikan gambaran sementara terhadap tingkat penerimaan sifat organoleptik sosis.

\section{Hasil analisis proksimat}

Hasil analisis proksimat formula sosis disajikan dalam Tabel 3. Berdasarkan hasil penelitian, sosis kontrol dan terbaik memiliki kadar air yang hampir sama, namun penambahan minyak atsiri kulit buah honje dapat menjadikan kadar air sosis terbaik lebih tinggi. Hal ini diduga akibat kontribusi kandungan air yang dimiliki minyak atsiri kulit buah honje. Kandungan air dari minyak atsiri dapat diketahui dari nilai indeks biasnya, menurut Guenther (1987) semakin banyak kandungan air, maka semakin kecil nilai indeks bias minyak atsiri. Hasil penelitian yang dilakukan Sukandar et al. (2014) menyatakan bahwa nilai indeks bias minyak atsiri kulit buah honje adalah sebesar 1,451 yang berarti lebih kecil dari nilai indeks bias minyak atsiri menurut BSN, 1998 yaitu 1,4853-1,4920.

Tabel 3. Hasil analisis proksimat sosis ayam

\begin{tabular}{lccc}
\hline \multirow{2}{*}{ Karakteristik } & \multicolumn{3}{c}{ Perlakuan } \\
\cline { 2 - 4 } & Kontrol & III & $\begin{array}{c}\text { SNI 01- } \\
3820-1995\end{array}$ \\
\hline Kadar air (\%) & 66,40 & 66,75 & Maks 67 \\
Kadar abu (\%) & 1,45 & 1,26 & Maks 3 \\
Kadar lemak (\%) & 1,10 & 2,90 & Maks 25 \\
Kadar protein (\%) & 26,25 & 23,10 & Min 13 \\
Kadar karbohidrat & 4,80 & 5,99 & Maks 8 \\
\hline
\end{tabular}

Keterangan: $\mathrm{III}=$ Sosis ayam dengan penambahan minyak ats iri kulit buah honje $160 \mu \mathrm{g} / \mathrm{mL}$

Hasil uji kadar abu untuk formula kontrol memiliki kadar abu $1,45 \%$, lebih tinggi dari formula sosis ayam terbaik yang memiliki kadar abu $1,26 \%$. Sedangkan hasil analisis kadar protein kedua formula sosis ayam cukup tinggi, ini dipengaruhi oleh bahan baku sosis yaitu daging ayam dan tepung tapioka, menurut Husak et al. (2008) kadar protein yang dimiliki daging ayam sejumlah $22,26 \%$ dan kadar protein dari tepung tapioka sebesar 0,29\% (Suprapti, 2005). Kadar lemak kedua formula sosis ayam, kontrol dan terbaik masih sesuai dan tidak melampaui standar mutu produk sosis begitu juga kadar karbohidrat kedua formula sosis karena standar mutu SNI untuk lemak sosis ialah maksimal $25 \%$ dan standar mutu SNI untuk karbohidrat yaitu maksimal $8 \%$. Semua karakteristik proksimat ini telah memenuhi standar mutu sosis BSN, 1995.

Hasil analisis cemaran logam dengan menggunakan instrument AAS menunjukkan bahwa sosis ayam kontrol dan terbaik tidak mengandung logam $\mathrm{Pb}$, tetapi mengandung logam esensial seperti $\mathrm{Cu}$ dan Zn yang jumlahnya berada di bawah batas maksimal yang ditetapkan Standar Nasional Indonesia (Tabel 4). Adanya kandungan logam Zn dan $\mathrm{Cu}$ dalam sosis ayam ini berperan sebagai pengkatalis pada pembentukan hidroperoksida. Agustina (2010) menyatakan bahwa logam berat merupakan unsur penting yang dibutuhkan setiap makhluk hidup. Contohnya sebagai trace element, 
logam berat yang esensial seperti tembaga (Cu), selenium ( $\mathrm{Se}$ ), Besi ( $\mathrm{Fe}$ ) dan Zink ( $\mathrm{Zn}$ ) penting untuk menjaga metabolisme tubuh manusia dalam jumlah yang tidak berlebihan, jika berlebihan akan menimbulkan toksik pada tubuh. Hidroperoksida (hasil oskidasi) terbentuk cepat dengan adanya radikal bebas dan logam-logam pengkatalis serta faktor cahaya atau panas.

Tabel 4. Cemaran logam pada sosis ayam

\begin{tabular}{lccc}
\hline \multirow{2}{*}{ Jenis logam } & \multicolumn{3}{c}{ Perlakuan } \\
\cline { 2 - 4 } & Kontrol & III & SNI01- \\
& & & $3820-1995$ \\
\hline Seng/Zn $(\mathrm{mg} / \mathrm{Kg})$ & 11,9 & 14,17 & Maks. 40 \\
Tembaga/Cu $(\mathrm{mg} / \mathrm{Kg})$ & 0,77 & 0,65 & Maks. 20 \\
Timbal/Pb $(\mathrm{mg} / \mathrm{Kg})$ & ND & ND & Maks. 0,03 \\
\hline K
\end{tabular}

Keterangan: ND = No Detected; III = Sosis ayam dengan penambahan minyak ats iri kulitbuah honje $160 \mu \mathrm{g} / \mathrm{mL}$

Hasil uji cemaran total bakteri formula sosis ayam kontrol dan formula sosis ayam terbaik tidak ditemukan adanya koloni bakteri atau negatif cemaran dan batas cemaran bakteri menurut mutu SNI, 1995 sosis yaitu maksimal $10^{5}$ koloni/g. Penambahan minyak atsiri kulit buah honje diduga memiliki peran dalam menghambat pertumbuhan mikroba. Dapat diduga bahwa pada kulit buah honje mengandung senyawa antimikroba seperti panda bunga honje, yang ternyata mampu menghambat pertumbuhan bakteri $S$. aureus, $L$. monocytogenes, $B$. cereus, S. typhimurium, E. coli, A. hydrophila dan $P$. aureginosa. Bakteri paling sensitif terhadap ekstrak etil asetat bunga honje adalah $P$. aeruginosa (Naufalin et.al, 2005).

Pencemaran bakteri pada produk pangan dapat dicegah dengan melakukan sterilisasi pada peralatan yang digunakan untuk proses pengolahannya, sterilisasi dilakukan dengan cara mencuci atau merebus peralatan dalam air panas. Selain itu perlakuan terhadap bahan baku juga dapat mempengaruhi adanya cemaran bakteri, Risnajati (2010) menyebutkan bahwa daging ayam memiliki beberapa kelemahan, terutama sifatnya yang mudah rusak (perishable). Kasih et al. (2012) menyebutkan sebagian besar kerusakan diakibatkan oleh penanganan yang kurang baik sehingga memberikan peluang bagi pertumbuhan mikroba pembusuk dan berdampak pada menurunnya kualitas serta daya simpan daging. Mikroba yang diujikan tidak spesifik terhadap mikroba tertentu tetapi berupa total cemaran konsorsium bakteri serta tidak diidentifikasi masing-masing bakteri yang tumbuh.

\section{KESIMPULAN}

Minyak atsiri kulit buah honje hasil distilasi memiliki rendemen sebesar $0,163 \%$ dan memiliki aktivitas antioksidan ( $\left(\mathrm{C}_{50}\right) \quad 21,296 \pm 0,789 \mathrm{mg} / \mathrm{mL}$.
Minyak atsiri kulit buah honje yang ditambahkan ke dalam sosis ayam memiliki pengaruh terhadap proses penghambatan kerusakan oksidatifnya yang ditunjukkan oleh berkurangnya pembentukan MDA sebesar $19,41 \%$ dibandingkan kontrol. Sosis ayam dengan konsentrasi minyak atsiri $160 \mu \mathrm{g} / \mathrm{mL}$ paling disukai dan memiliki daya hambat oksidatif tertinggi yaitu sebesar $19,41 \%$ dan memiliki karakteristik proksimat yang memenuhi standar mutu sosis SNI 01-3820-1995.

\section{UCAPAN TERIMA KASIH}

Terima kasih kepada semua pihak yang telah membantu penelitian ini, khususnya kepada Kepala Pusat Laboratorium Terpadu UIN Syarif Hidayatullah Jakarta yang telah memfasilitasi hingga penelitian ini terlaksana dengan baik. Ucapan terimakasih juga disampaikan kepada Kepala Pusat Penelitian dan Penerbitan Lembaga Penelitian dan Pengabdian kepada Masyarakat UIN Syarif Hidayatullah Jakarta yang telah mendanai kegiatan penelitian ini.

\section{DAFTAR PUSTAKA}

Agustina T. 2010. Kontaminasi logam berat pada makanan dan dampaknya pada kesehatan. J Teknol Busana Boga 2: 53-65.

Aini N, Purwono B, Tahir I. 2007. Structure antioxidant activities relationship analysis of isoeugenol, eugenol, vanilin and their derivates. Ind $\mathrm{J}$ Chem 7: 61-66. DOI: 10.22146/ijc.276.

[BSN] Badan Standarisasi Nasional. 1995. Sosis Daging. Jakarta (ID): SNI 01-3820-1995.

[BSN] Badan Standarisasi Nasional. 1998. Cara Uji Cemaran Logamdalam Makanan. Jakarta (ID): SNI 01-2896-1998.

Bangol E, Momuat LI, Abidjulu J. 2014. Aktivitas antioksidan ekstrak etanol dan $n$-heksana dari daun rumput santa maria (Artemisia vulgaris L.) pada minyak ikan). J Ilmiah Sains 14: 129-135. DOI: $10.1234 /$ jis.v14i2.6117.

Bradley EM, Williams JB, Schilling MW, Coggins PC, Crist C, Yoder S, Campano SG. 2011. Effects of sodium lactate and acetic acid derivatives on the quality and sensory characteristics of hot-boned pork sausage patties. Meat Sci 88: 145-150. DOI: 10.1016/j.meatsci. 2010.12.015.

Cahyana H, Mardiana L. 2003. Senyawa kimia minyak atsiri andaliman (Zanthoxylum acanthopodium DC) dan kemampuan sebagai antioksidan alami. J Ilmu Teknologi Pangan 1: 106111. 
Chan EWC, Lim YY, Omar M. 2007. Antioxidant and antibacterial activity of leaves of Etlingera species (Zingiberaceae) in Peninsular Malaysia. Food Chem 104: 1586-1593. DOI: 10.1016/j. foodchem.2007.03.023.

DeMan JM. 1999. Principles of Food Chemistry. $3^{\text {rd }}$ Ed. 57-61. Aspen Pub Inc, Gaithersbury, Marylan US.

Fardiaz S. 1992. Mikrobiologi Pangan 1. 135. Jakarta (ID): Gramedia Pustaka Utama.

Fitriana WD, Fatmawati S, Ersam T. 2015. Uji antioksidan terhadap DPPH dan ABTS dari fraksifraksi daun kelor (Moringa oleifera). Prosiding Simposium Nasional Inovasi dan Pembelajaran Sains 2015. Institut Teknologi Bandung. p 172 Bandung (ID).

Guenther E. 1987. Minyak Atsiri. Diterjemahkan oleh Ketaren RS, Mulyono R. 44-484. Jakarta (ID): UI Press.

Howard R, Moskowitz, Jacqueline H, Beckley, Anna VA Resurreccion. 2012. Sensory and Consumer Research in Food Product Design and Development. $2^{\text {nd }}$ Ed. 229-281. Blackwell Publishing Ltd. and the Institute of Food Technologists. Spain. DOI: 10.1002/97811199459 70.

Jaafar FM, Osman CP, Ismail NH, Awang K. 2007. Analysis of essential oils of leaves, stems, flowers and rhizomes of Etlingera elatior (JACK) R.M. Smith. Malaysian J Anal Sci 11: 269-273.

Husak RL, Sebranek J G, Bregendahl K. 2008. A survey of commercially available broilers marketed as organic, free-range, and conventional broilers for cooked meat yields, meat composition, and relative value. Poult Sci 87: 23672376. DOI: $10.3382 /$ ps.2007-00294.

Kasih NS, Jaelani A, Firahmi N. 2012. Pengaruh lama penyimpanan daging ayam segar dalam refrigerator terhadap $\mathrm{pH}$, susut masak dan organoleptik. Media Sains 4: 154-159.

Kingchaiyaphum W, Chitsiri R. 2012. Antimicrobial and antioxidative activities of essential oils in Chinese sausage (Kun-Chiang). As J Food AgInd 5: 156-162.

Kurniawan J, Widjanarko SB. 2013. Studi kasus analisa proksimat, kandungan kalori, dan aspek keamanan pangan minuman es di sekitar Universitas Brawijaya. J Pangan Agroin 1: 5664.

Legowo AM, Soepardie, Miranda R, Nur Annisa IS, Rohidayah Y. 2002. Pengaruh perendaman daging pra kyuring dalam jus daun sirih terhadap ketengikan dan sifat organoleptik dendeng sapi selama penyimpanan, J Teknol Industri Pangan 12: 64-69.

Min DB, Boff JM. 2002. Food Lipids Chemistry, Nutrition, and Biotechnology. $2^{\text {nd }}$ Ed. Chapter 11: Lipid Oxidation of Edible Oil. 335. CRC Press. Marcel Dekker Inc. New York. DOI: 10.1201/9780203908815.pt3.

Mudawaroch RE, Zulfanita. 2012. Kajian berbagai macam antioksidan alami dalam pembuatan sosis. Surya Agritama 1: 71-84.

Naufalin R, Jenie BSL, Kusnandar F, Sudarwanto M, Rukmini H. 2005. Aktivitas antibakteri ekstrak bunga kecombrang terhadap bakteri patogen dan perusak pangan. J Teknol Industri Pangan XVI: 119-125.

Politeo O, Jukic M, Milos M. 2006. Chemical composition and antioxidant activity of essential oils of twelve spice plants. Croat Chem Acta 79: 545-552.

Porter NA, Caldwell SE, Mills KA. 1995. Mechanisms of free radical oxidation of unsaturated lipid. Lipids 30: 277-290.

Risnajati D. 2010. Pengaruh lama penyimpanan dalam lemari es terhadap $\mathrm{PH}$, daya ikat air, dan susut masak karkas broiler yang dikemas plastik polyethylen. J IImiah IImu-IImu Peternakan 13: 309-315.

Soekarto ST, Hubeis M. 1991. Metodologi Penelitian Organoleptik, Pusat antar Universitas Pangan dan Gizi, Bogor (ID): Institut Pertanian Bogor.

Sukandar D, Eka RA, Adi R, Ramma N. 2014. Characteristic and Activities Antibacterial of Honje Fruit Skin (Etlingera elatior) Essential Oil [Laporan Penelitian Berbasis Publikasi Nasional Terak reditasi]. Jakarta (ID): Puslitpen-LP2M UIN Syarif Hidayatullah.

Suprapti L. 2005. Tepung Tapioka Pembuatan dan Pemanfaatannya. 22-24. Kanisius. Yogyakarta (ID).

Vural H. 2003. Effect of replacing beef fat and tail fat with interesterified plant oil on quality characteristics of turkish semi-dry fermented sausages. Eur Food Res Technol 217: 100-103. DOI: 10.1007/s00217-003-0727-y.

Zhang $\mathrm{H}$, Feng C, Wang $X$ Yao HY. 2006. Evaluation of antioxidant activity of parsley (Petroselinum crispum) essential oil and identification of its antioxidant constituents. Food Res Int Food 39: 833-839. DOI: 10.1016/j.foodres. 2006.03.007. 